\title{
Pilosella argyrogaliciana, $P$. argyrolegionensis and $P$. megargyrocoma (Asteraceae): three new species from the Cantabrian Mountains (N. Spain)
}

\author{
Fermín del Egido Mazuelas (*) \& Gonzalo Mateo Sanz (**)
}

\begin{abstract}
Egido Mazuelas, F. \& Mateo Sanz, G. Pilosella argyrogaliciana, P. argyrolegionensis and P. megargyrocoma (Asteraceae): three new species from the Cantabrian Mountains (N Spain). Lazaroa 34: 11-17. (2013).

In this paper, we describe three new species of Pilosella (Asteraceae) from the Cantabrian Mountains (N Spain): $P$. argyrogaliciana Mateo \& Egido, P. argyrolegionensis Mateo \& Egido and P. megargyrocoma Mateo \& Egido. All of them are intermediate species of P. argyrocoma, endemic to the S, C and NW Iberian Peninsula and N Africa. For each species, we provide a detailed description, together with a discussion and a table with the diagnostic morphological characters used to separate these species from their morphologically closest species. We also provide images of type material.
\end{abstract}

Keywords: Pilosella, Asteraceae, taxonomy, new species, Spain.

Resumen: del Egido Mazuelas, F. \& Mateo Sanz, G. Pilosella argyrogaliciana, P. argyrolegionensis y P. megargyrocoma (Asteraceae): tres nuevas especies de la Cordillera Cantábrica (N España). Lazaroa 34: 11-17. (2013).

Se describen tres nuevas especies de Pilosella (Asteraceae) procedentes de la Cordillera Cantábrica (N España): $P$. argyrogaliciana Mateo \& Egido, P. argyrolegionensis Mateo \& Egido y P. megargyrocoma Mateo \& Egido. Las tres son especies intermedias de P. argyrocoma, endémica del S, C y NW de la Península Ibérica y N de África. Para cada especie se aporta una descripción detallada, junto con una discusión y una tabla con los caracteres diagnósticos útiles para separar estas nuevas especies de las más próximas. Se aportan también imágenes del material tipo de las tres nuevas especies.

Palabras clave: Pilosella, Asteraceae, taxonomía, nuevas especies, España.

\section{INTRODUCTION}

This work is a continuation of the intense study we are making in the genus Pilosella in the area of the Cantabrian Mountains (MATEO \& DEL EGIDO, 2007, 2010, 2011, 2012a, 2012b; DEL EGIDO \& MATEO, 2012) and takes place in the context of the monographic revision of this genus in the Iberian Peninsula started years ago (MATEO, 1988). This monographic revision reached a relatively mature synthesis in more recent times (MATEO, 2006) and its results are included in the large volume 2 of MedChecklist (GREUTER \& RAABE-STRAUBE, 2008).

In our exhaustive tours through the Cantabrian Mountains DEL EGIDO \& PUenTe, 2011a, b; DEL
EGIDO \& al., 2012 in search of the diverse representation of species of Pilosella, we detected some important populations of $P$. argyrocoma and two of its intermediate species: P. nevadensis (argyrocoma $<>$ saussureoides) and P. subulatissima (argyrocoma <> pseudopilosella) (MATEO $\&$ DEL EGIDO, 2011). In the environment of $P$. argyrocoma we also detected three new intermediate species that we describe and comment here.

Pilosella argyrocoma is a basic species of the sect. Pilosellina and it is well characterized basically by having monocephalic scapes, short and relatively thick (or absent) stolons, dense white stellate trichomes on both adaxial and abaxial surfaces of the leaves and abundant long simple

\footnotetext{
* Departamento de Biodiversidad y Gestión Ambiental (Área de Botánica). Facultad de CC Biológicas y Ambientales. Campus de Vegazana. Universidad de León. E-24071 León. Spain. E-mail: fegim@unileon.es

** Jardín Botánico e Instituto Cavanilles de Biodiversidad y Biología Evolutiva. Universidad de Valencia. C/Quart, 80. E46008-Valencia. Spain. E-mail: gonzalo.mateo@uv.es.
} 
eglandular and stellate trichomes on involucral bracts and scapes. It is an endemic species to the $\mathrm{S}, \mathrm{C}$ and NW Iberian Peninsula and N Africa (MATEO \& DEL EGIDO, 2011). There are only three intermediate species described which are thought to have resulted from hybridisation of P. argyrocoma: $P$. aranii (argyrocoma $<>$ vahlii), only known in its classic locality in the Sierra de Guadarrama (MATEO 1997; 2006); P. nevadensis (argyrocoma $<>$ saussureoides), known in the Sierra Nevada and its surroundings, the Central System and a pair of localities in the Cantabrian Mountains (MAteo, 1997; 2006; Mateo \& DEl Egido, 2011); and $P$. subulatissima (argyrocoma $\diamond$ pseudopilosella), only known in its classic locality in the Sierra del Cuarto (Granada), the Sierra de Guadarrama and three localities in the Cantabrian Mountains (MATEO, 2006; MATEO \& DEl EgIDO, 2011).

The taxonomic treatment of the genus follows BRÄUTIGAM \& GREUTER (2007; 2008) (see also DEL EGIDO \& MATEO, 2012) and the nomenclature of taxa cited can be consulted in BRÄUTIGAM \& GREUTER (2008). After the names of the intermediate taxa, we indicate (in parentheses) the species that are most probably responsible for their origin.

\section{RESULTS}

Pilosella argyrogaliciana Mateo \& Egido spec. nova (argyrocoma $<>$ galiciana) (Figure 1)

Holotypus: Spain. León, Cármenes, Canseco, pr. Pico Morala, 30TTN974136415, 2100 m, pastizal psicroxerófilo acidófilo, 28.VI.2009, F. del Egido, (holotype: LEB 103233). - Paratype: Spain. León, Valdelugueros, Redilluera, Sierra de Portillas, 30TTN9888863868, 1985 m, pastizal psicroxerófilo en zona de mezcla de sustratos, 28.VI.2009, F. del Egido, LEB 103229.

Diagnosis: Plantae rosulatae, stolonibus brevibus vel nullis. Folia ad 2-6 x 0.4-1.7 cm, elliptica oblonga vel oblaceolata, obtuso-mucronata, attenuata, subcoriacea, supra viridia, laxe subrigido-pilosa et floccosa, subtus laxe vel dense cano-floccosa, pilosa, eglandulosa. Scapi (2.5) 615 (18) cm x 1-2 mm alti, monocephali, modice floccosi, ad apicem pilosi et glandulosi. Involucra
7-12 x 6-11 mm. Bracteae lanceolato-lineares, 1 mm latae, acutae, dense pilosiae, modice floccosae et glandulosae.

Description: Perennial herb. Phyllopodous. Stolons absent or if present, scarce, short (up to 4 $\mathrm{cm}$ in studied specimens) and stout, with leaves smaller than those of the rosette. Rosette-leaves 2-6 x 0.4-1.7 cm; entire; elliptical, oblong, oblanceolate or linear-oblanceolate; rounded-obtuse or slightly mucronate at apex and gradually narrowing towards base; adaxial surface green or lightly greyish, with some subrigid long simple eglandular trichomes and, in some leaves, with few to numerous stellate trichomes (absent in others); abaxial surface green to greyish-green or whitish, with few (or even absent in some leaves) to numerous (variable from one leaf to another) stellate trichomes and some long simple eglandular trichomes thinner than those of the adaxial surface; without glandular trichomes. Scapes

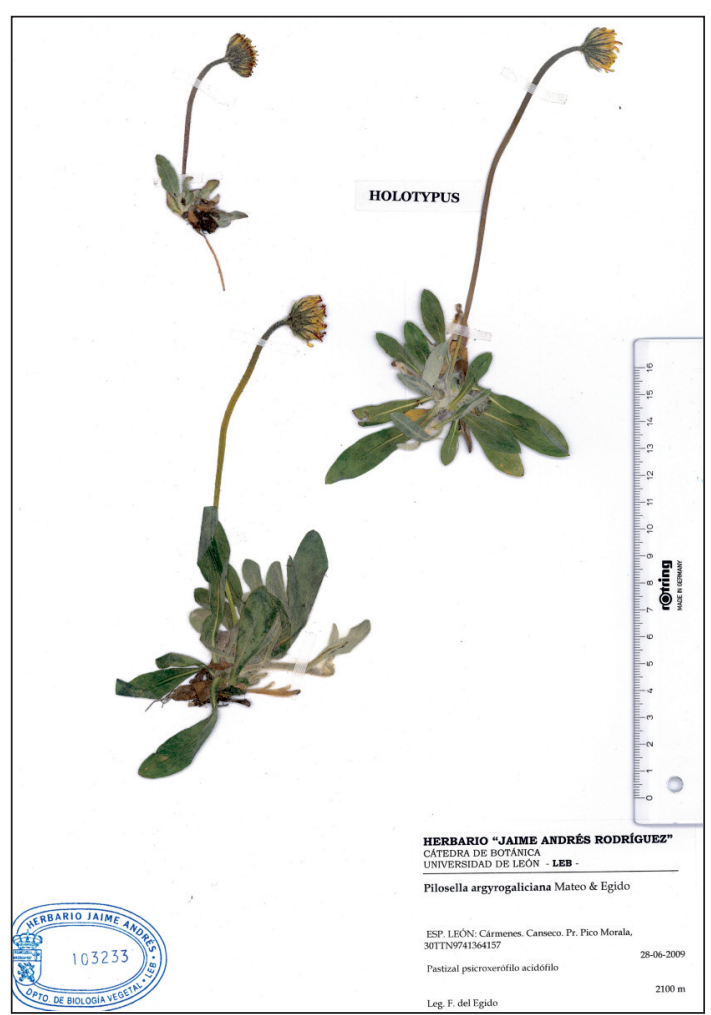

Figure 1. - Holotype of Pilosella argyrogaliciana Mateo \& Egido spec. nova. 
(2.5) 6-15 (18) $\mathrm{cm}$ tall and 1-2 $\mathrm{mm}$ in diameter, each with a single capitulum in studied specimens (it may have more), with stellate, glandular and simple eglandular trichomes in variable quantities, the most abundant being the stellate ones along the whole length of the stem whereas the simple eglandular and glandular ones are generally scarce towards base becoming more abundant towards apex. Involucre 7-12 x 6-11 mm. Involucral bracts linear-lanceolate, acute, $\pm 1 \mathrm{~mm}$ wide; with stellate, glandular and long simple eglandular trichomes in more or less similar proportions (generally, the eglandular trichomes are the most abundant). Ligules yellow, the outer with a dark red stripe on outer face.

Affinities: P. argyrogaliciana occupies an intermediate morphological position between $P$. argyrocoma and P. galiciana, and the influence of both species is very clear and unequivocal. Its principal differences from those are presented in Table 1 . It is evident that $P$. argyrogaliciana has resulted from hybridisation of a species of the sect. Pilosellina (it has monocephalic scapes, stellate trichomes on abaxial surface of leaves, etc.) and a species of the sect. Auriculina (it has some leaves with very few, or absent, stellate trichomes on abaxial surface of leaves). The species of the sect. Pilosellina must have stellate trichomes also on adaxial surface of leaves, stolons absent or, if present, scarce, short and relatively thick and thin involucral bracts with abundant and dominant long simple eglandular trichomes and more or less abundant stellate trichomes: in this area it can only be $P$. argyrocoma. The species of the sect. Auriculina must have stolons absent or, if present, scarce, short and stout, leaves without glandular trichomes, and thin involucral bracts with glandular (generally the most abundant), stellate and simple eglandular trichomes in similar proportions: in this area it can only be $P$. galiciana.

Furthermore, as P. galiciana and $P$. vahlii are very similar, the most similar species to $P$. argyrogaliciana is P. aranii (argyrocoma $<>$ vahlii). The basic difference between these two species is that $P$. aranii presents some glandular trichomes on the leaves due to the influence of $P$. vahli. The other species which are thought to have resulted from hybridisation of P. argyrocoma: P. nevadensis (argyrocoma $<>$ saussureoides), $P$. subulatissima (argyrocoma $\diamond$ pseudopilosella) and the two species described below in this paper, are less similar. $P$. argyrogaliciana differs clearly from all of them, among other characters, because it has abaxial surface of some leaves with few or absent stellate trichomes due to the influence of a species of the sect. Auriculina (these other four species have abaxial surface of all leaves with dense stellate trichomes).

Table 1

Principal morphological differences between Pilosella argyrocoma, P. argyrogaliciana sp. nova and P. galiciana.

\begin{tabular}{llll}
\hline Characters & P.argyrocoma & P.argyrogaliciana & P. galiciana \\
\hline Number of capitula & 1 & 1 & $1-4(6)$ \\
Stellate trichomes & abundant on both surfaces & few to numerous on & absent \\
on leaves & of all leaves & adaxial surface of some \\
& leaves and absent on others; \\
& few to numerous on \\
& abaxial surface of some \\
& leaves and absent on \\
& others
\end{tabular}

\begin{tabular}{llll} 
Indumentum of & very dense, with & very dense, with stellate, & not very dense, with \\
involucral bracts & dominant long simple & glandular and long simple & glandular, stellate and \\
& eglandular trichomes, & eglandular trichomes in & simple eglandular \\
\pm abundant stellate & more or less similar & trichomes in \pm similar \\
trichomes and very scarce & proportions (generally & proportions (generally \\
& or absent glandular & simple eglandular ones & glandular ones most \\
trichomes & most abundant) & abundant) \\
\hline
\end{tabular}


Distribution: P. argyrogaliciana is endemic to the NW Iberian Peninsula. It must be very rare because $P$. galiciana is a very local and scarce plant only present in mountainous areas of the NW Iberian Peninsula and P. argyrocoma is very rare in the NW Iberian Peninsula.

Pilosella argyrolegionensis Mateo \& Egido spec. nova (argyrocoma <> officinarum) (Figure 2)

Holotypus: Spain. León, Valdelugueros, Redilluera, Sierra de Portillas, 30TTN9888863868, $1985 \mathrm{~m}$, pastizal psicroxerófilo en zona de mezcla de sustratos, 28.VI.2009, F. del Egido (holotype LEB 103231; isotype VAL). - Paratype: Spain. León, San Emiliano-Sena de Luna, Riolago de Babia, Pico La Ferrera, 29TQH3717253588, 2110 m, pastizal psicroxerófilo acidófilo, 28.VII.2009, F. del Egido \& E. Puente (LEB 82159; VAL).

Diagnosis: Plantae rosulatae, stolonibus brevibus vel \pm elongatis $(0.5-8 \mathrm{~cm})$, foliis parvis ob-

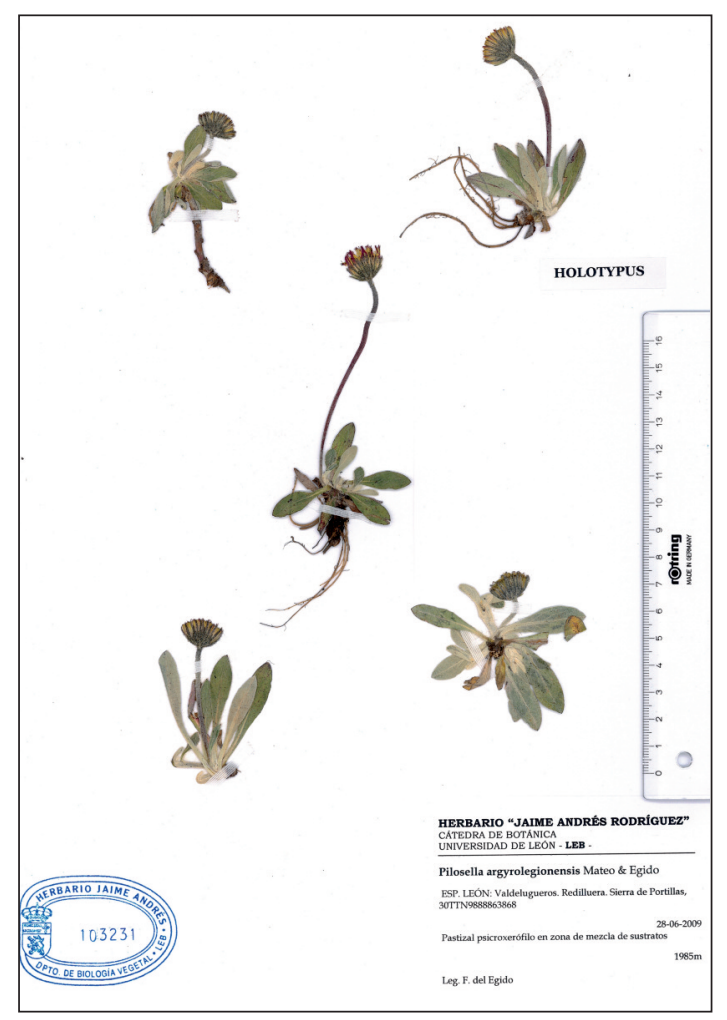

Figure 2.-Holotype of Pilosella argyrolegionensis Mateo \& Egido spec. nova. siti. Folia ad (1.5) 3-5 (7) x 0.6-2 cm, elliptica oblonga vel oblaceolata, obtuso-mucronata, attenuata, supra viridia, laxe subrigido-pilosa et floccosa, subtus laxe vel dense cano-floccosa, pilosa, eglandulosa. Scapi 4-20 cm x 1-1.5 mm alti, monocephali, modice floccosi, ad apicem pilosi et glandulosi. Involucra 8-13 x 6-11 mm. Bracteae lanceolato-lineares, $1 \mathrm{~mm}$ latae, acutae, modice pilosae floccosae et glandulosae.

Description: Perennial herb. Phyllopodous. Stolons scarce, very short to relatively long $(0.5-8 \mathrm{~cm}$ in the studied specimens), with leaves smaller than those of the rosette. Rosette-leaves (1.5) 3-5 (7) x 0.6-2 cm; entire; elliptical, oblong, oblanceolate or linear-oblanceolate; rounded-obtuse and slightly mucronate at apex, gradually narrowing towards base; adaxial surface green or greyish, with some subrigid long simple eglandular trichomes and, in some leaves, with few to numerous stellate trichomes (absent in others); abaxial surface whitish, with dense stellate trichomes and some long simple eglandular trichomes thinner than those of the adaxial surface. Scapes thin (1-1.5 $\mathrm{mm}$ in diameter); 4-20 cm tall; each with a single capitulum; with stellate, glandular and long simple eglandular trichomes in variable quantities (the stellate trichomes are the most abundant along whole length of the stem followed by the glandular trichomes, which become more abundant towards apex, whereas the simple trichomes appear more or less scattered along whole length of the stem but are more abundant at base and apex). Involucre 8-13 x 6-11 $\mathrm{mm}$. Involucral bracts linear-lanceolate, acute, \pm 1 $\mathrm{mm}$ wide; with stellate, glandular and simple eglandular trichomes in more or less similar proportions. Ligules yellow, the outer with a dark red stripe on outer face.

Affinities: P. argyrolegionensis occupies an intermediate morphological position between $P$. argyrocoma and $P$. officinarum, and the influence of both species is very clear and unequivocal. Its principal differences from those are presented in Table 2 . It is evident that $P$. argyrogaliciana has resulted from hybridisation of two species of the sect. Pilosellina (it has monocephalic scapes, dense stellate trichomes on abaxial surface of all 
Table 2

Principal differences between Pilosella argyrocoma, P. argyrolegionensis sp. nova and P. officinarum.

\begin{tabular}{|c|c|c|c|}
\hline Characters & P. argyrocoma & P. argyrolegionensis & P. officinarum \\
\hline Stolons & $\begin{array}{l}\text { absent or, if present, } \\
\text { scarce, short and } \\
\text { relatively thick }\end{array}$ & $\begin{array}{l}\text { scarce, very short to } \\
\text { relatively long }\end{array}$ & $\begin{array}{l}\text { abundant, elongated and } \\
\text { thin }\end{array}$ \\
\hline $\begin{array}{l}\text { Stellate trichomes on } \\
\text { leaves }\end{array}$ & $\begin{array}{l}\text { abundant on both surfaces } \\
\text { of all leaves }\end{array}$ & $\begin{array}{l}\text { few to numerous on } \\
\text { adaxial surface of some } \\
\text { leaves and absent on } \\
\text { others; very dense on } \\
\text { abaxial surface of all leaves }\end{array}$ & $\begin{array}{l}\text { absent on adaxial surface } \\
\text { of all leaves and very } \\
\text { dense on abaxial surface } \\
\text { of all leaves }\end{array}$ \\
\hline $\begin{array}{l}\text { Indumentum of involucral } \\
\text { bracts }\end{array}$ & $\begin{array}{l}\text { very dense, with dominant } \\
\text { long simple eglandular } \\
\text { trichomes, } \pm \text { abundant } \\
\text { stellate trichomes and } \\
\text { very scarce or absent } \\
\text { glandular trichomes }\end{array}$ & $\begin{array}{l}\text { very dense, with stellate, } \\
\text { glandular and long simple } \\
\text { eglandular trichomes in } \\
\pm \text { similar proportions }\end{array}$ & $\begin{array}{l}\text { very dense, with abundant } \\
\text { black glandular trichomes, } \\
\text { scarce to moderate stellate } \\
\text { trichomes and scarce or } \\
\text { absent simple eglandular } \\
\text { trichomes }\end{array}$ \\
\hline
\end{tabular}

leaves, etc.). One of them must have stellate trichomes also on adaxial surface of leaves, stolons absent or, if present, scarce, short and relatively thick and thin involucral bracts with abundant and dominant long simple eglandular trichomes and more or less abundant stellate trichomes: in this area it can only again be P. argyrocoma. The other species must have abundant, elongated and thin stolons and thin involucral bracts with abundant and dominant black glandular trichomes: in this area it can only be P. officinarum.

$P$. argyrolegionensis is similar to the other species which are thought to have resulted from hybridisation of P. argyrocoma and other species of the sect. Pilosellina: P. nevadensis (argyrocoma $<>$ saussureoides), and P. subulatissima (argyrocoma $<>$ pseudopilosella). P. argyrolegionensis differs from both of them basically by the involucral bracts and apex of scapes with abundant black glandular trichomes due to the influence of $P$. officinarum (the involucral bracts and apex of scapes of these other two species have very scarce glandular trichomes, or they may even be absent). The abaxial surface with dense stellate trichomes on all leaves, among other characters, distinguishes this species from P. argyrogaliciana (described above) and from P. aranii (argyrocoma $<>$ vahlii).

Distribution: $P$. argyrolegionensis is only known in two localities in the Cantabrian Moun- tains. It can also occur in some areas of the $\mathrm{C}$ and S Iberian Peninsula although P. officinarum is very rare in these areas.

Pilosella megargyrocoma Mateo \& Egido spec. nova (argyrocoma $\diamond$ peleteriana) (Figure 3 )

Holotypus: Spain. León, Carrocera, Piedrasecha, Collado del Fito, 30TTN7443747896, 1670 m, brezal, 14.VII.2009, F. del Egido (holotype LEB 103251; isotype VAL 202513). - Paratype: Spain. León, San Emiliano-Sena de Luna, Riolago de Babia, La Ferrera peak, 29TQH371535, 2110 m, pastizal psicroxerófilo acidófilo, 28.VII.2009, F. del Egido \& E. Puente, LEB 107301.

Diagnosis: Plantae rosulatae, stolonibus brevibus vel nullis. Folia ad 4-11 $\times 0.8-2.5 \mathrm{~cm}$, elliptica oblonga vel oblanceolata, obtusa vel obtuso-mucronata, attenuata, supra modice vel laxe floccosa, laxe subrigido-pilosa, subtus densiore cano-floccosa, modice pilosa. Scapi 30-40 (55) cm x 1.5-2 $\mathrm{mm}$ alti, monocephali, modice floccosi pilosi et glandulosi. Involucra magna, 13-15 x 10-14 mm. Bracteae lanceolato-lineares, 1.2-1.6 mm latae, acutae, dense pilosae, modice floccosae, laxe glandulosae.

Description: Perennial herb. Phyllopodous. Stolons absent or if present, scarce, relatively short (up to $9 \mathrm{~cm}$ in studied specimens) and stout, with lea- 


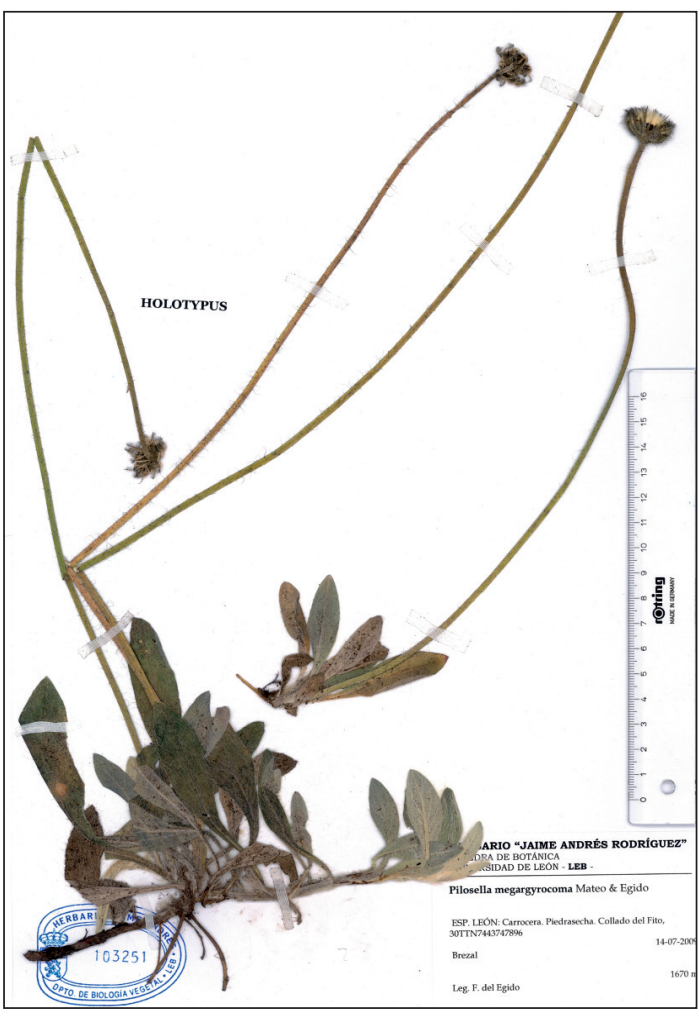

Figure 3. - Holotype of Pilosella megargyrocoma Mateo \& Egido spec. nova.

ves a little smaller than those of the rosette. Rosette-leaves 4-11 x 0.8-2.5 cm; entire; elliptical, oblong or oblanceolate; rounded-obtuse or slightly mucronate at apex, gradually narrowing towards base; adaxial surface green or greyish, with some very long subrigid (4-7 $\mathrm{mm}$ ) simple eglandular trichomes and, in some leaves, with few to numerous stellate trichomes (absent in others); abaxial surface whitish, with dense stellate trichomes and some long simple eglandular trichomes thinner than those of the adaxial surface. Scapes stout (1.5$2 \mathrm{~mm}$ in diameter); 30-40 (55) $\mathrm{cm}$ tall; each with a single capitulum; with stellate, glandular and very long simple eglandular trichomes in more or less similar proportions. Involucre 13-15 x 10-14 $\mathrm{mm}$. Involucral bracts linear-lanceolate, acute, 1.2$1.6 \mathrm{~mm}$ wide; with dominant long greyish (black at base) simple eglandular trichomes that cover other quite abundant stellate trichomes and some occasional glandular trichomes.

Affinities: P. megargyrocoma occupies an intermediate morphological position between $P$. argyrocoma and P. peleteriana, and the influence of both species is very clear and unequivocal. Its principal differences from those are presented in Table 3. As with P. argyrolegionensis, it is evident that $P$. megargyrocoma has resulted from hybridisation of two species of the sect. Pilosellina and one of them must again be P. argyrocoma for the same reasons. The other species must have scarce, short or not very long and stout stolons with leaves similar than those of the rosette, thicker scapes and capitula, and wider involucral bracts with dominant long simple eglandular trichomes: in this area it can only be P. peleteriana.

Table 3

Principal differences between Pilosella argyrocoma, P. megargyrocoma sp. nova and P. peleteriana.

\begin{tabular}{|c|c|c|c|}
\hline Characters & P. argyrocoma & P. megargyrocoma & P. peleteriana \\
\hline $\begin{array}{l}\text { Stellate trichomes on } \\
\text { leaves }\end{array}$ & $\begin{array}{l}\text { abundant on both surfaces } \\
\text { of all leaves }\end{array}$ & $\begin{array}{l}\text { few to numerous on } \\
\text { adaxial surface of some } \\
\text { leaves and absent on others; } \\
\text { very dense on abaxial } \\
\text { surface of all leaves }\end{array}$ & $\begin{array}{l}\text { absent on adaxial surface of } \\
\text { all leaves and very dense } \\
\text { on abaxial surface }\end{array}$ \\
\hline Diameter of scapes & $1-1.5 \mathrm{~mm}$ & $1.5-2 \mathrm{~mm}$ & $\pm 2 \mathrm{~mm}$ \\
\hline Width of involucral bracts & $\pm 1 \mathrm{~mm}$ & $1.2-1.6 \mathrm{~mm}$ & up to $2-3 \mathrm{~mm}$ \\
\hline $\begin{array}{l}\text { Indumentum of involucral } \\
\text { bracts }\end{array}$ & $\begin{array}{l}\text { very dense, with dominant } \\
\text { long simple eglandular } \\
\text { trichomes, } \pm \text { abundant } \\
\text { stellate trichomes and very } \\
\text { scarce or absent glandular } \\
\text { trichomes }\end{array}$ & $\begin{array}{l}\text { very dense, with dominant } \\
\text { long simple eglandular } \\
\text { trichomes, quite abundant } \\
\text { stellate trichomes and very } \\
\text { scarce glandular trichomes }\end{array}$ & $\begin{array}{l}\text { very dense, with dominant } \\
\text { very long simple eglandular } \\
\text { trichomes and very scarce } \\
\text { or absent glandular } \\
\text { trichomes and/or stellate } \\
\text { trichomes }\end{array}$ \\
\hline
\end{tabular}


P. megargyrocoma differs clearly from all the other species which are thought to have resulted from hybridisation of P. argyrocoma because it is more robust, with thicker scapes and capitula, wider involucral bracts, larger leaves of the stolons, among other characters.
Distribution: P. megargyrocoma is only known in two localities in the Cantabrian Mountains. It can also occur in some areas of the center of the Iberian Peninsula although $P$. peleteriana is very rare in these areas.

\section{REFERENCES}

Bräutigam, S. \& Greuter, W. -2007- A new treatment of Pilosella for the Euro-Mediterranean flora [Notulae ad floram euro-mediterraneam pertinentes No. 24] - Willdenow. 37: 123-137.

Bräutigam, S. \& Greuter, W. -2008 - Pilosella Vaill. - In: Greuter, W. \& Raabe-Straube E. (Eds.). Med-Checklist. A critical inventory of vascular plants of the circum-mediterranean countries, 2. Dicotyledones (Compositae). Pp. 559-674. OPTIMA, Palermo, Genève \& Berlin.

Del Egido, F. \& Puente, E. -2011a - Valeriano apulae-Potentilletum nivalis y Festuco eskiae-Cytisetum oromediterranei: dos nuevas comunidades vegetales de la alta montaña cantábrica - Lazaroa 32: 91-99.

Del Egido, F. del \& Puente, E. - 2011b- Sobre los nombres correctos de dos asociaciones homónimas: Epipactido palustris-Eriophoretum latifolii - Lazaroa 32: 181-182.

Del Egido, F., Fernández, M., Ferreras, N., Puente, E. \& López, M.J. -2012 - Notas sobre flora leonesa amenazada, II - Lazaroa 33: 207-216.

Del Egido, F. \& Mateo, G. - 2012- Three new species of Pilosella (Asteraceae) from the Cantabrian Mountains, N Spain - Ann. Bot. Fenn 49: 271-278.

Greuter, W. \& Raabe-Straube, E. (eds.) - 2008- MedChecklist. A critical inventory of vascular plants of the circum-mediterranean countries, 2. Dicotyledones
(Compositae) - OPTIMA, Palermo, Genève \& Berlin. Mateo, G. - 1988 - Sobre las especies del género Hieracium sect. Pilosellina Fr. - Lagascalia 15 (extra): 369-376.

Mateo, G. - 1997- Sobre Pilosella argyrocoma (Fr.) F.W. Schultz \& Schultz Bip. y especies relacionadas - Flora Montiberica 7: 67-71.

Mateo, G. -2006- Aportaciones al conocimiento del género Pilosella Hill en España, VII. Revisión sintética Flora Montiberica 32: 51-71.

Mateo, G. \& del Egido, F. - 2007- Novedades del género Pilosella Hill (Compositae) en los montes astur-leoneses - Flora Montiberica 37: 3-16.

Mateo, G. \& del Egido, F. - 2010 - Novedades del género Pilosella Hill (Compositae) en los montes astur-leoneses, II - Flora Montiberica 44: 72-79.

Mateo, G. \& del Egido, F. - 2011 - Novedades del género Pilosella Hill (Compositae) en los montes astur-leoneses, III - Flora Montiberica 48: 38-51.

Mateo, G. \& del Egido, F. -2012a - Novedades del género Pilosella Hill (Compositae) en los montes astur-leoneses, IV - Flora Montiberica 52: 78-84.

Mateo, G. \& del Egido, F. -2012b- Pilosella lactocantabrica (Asteraceae, Cichorieae), a new species from the Cantabrian Mountains (N Spain), and two new related species - Willdenowia 42: 181-189. 